\title{
TRANSFORMASI PRINSIP DASAR JAMINAN FIDUSIA PASCA PUTUSAN MAHKAMAH KONSTITUSI NOMOR 18/PUU-XVII/2019
}

\author{
Izzy Al Kautsar \\ Universitas Muhammadiyah Yogyakarta, \\ J1. Brawijaya Daerah Istimewa Yogyakarta 55183, \\ alkautsarizzy@gmail.com \\ Ahdiana Yuni Lestari \\ Universitas Muhammadiyah Yogyakarta, \\ J1. Brawijaya, Daerah Istimewa Yogyakarta 55183, \\ ahdianayunilestari@umy.ac.id
}

\begin{abstract}
Abstrak
Tujuan dari penelitian ini adalah untuk menganalisa sejauh mana peran notaris dalam pembuatan perjanjian fidusia, serta menganalisa kepastian hukum dan keadilan dalam pelaksanaan eksekusi obyek jaminan fidusia bagi para pihak pasca putusan Mahkamah Konstitusi nomor 18/PUU-XVII/2019. Penelitian ini menggunakan metode yuridis normatif dengan pendekatan perundang-undangan, dan menggunakan data sekunder yang terdiri dari bahan hukum primer, sekunder dan tersier. Penelitian ini bersifat deskriptif untuk menggambarkan kedudukan notaris dalam pembuatan perjanjian jaminan fidusia serta pemenuhan asas kepastian hukum dan keadilan dalam pelaksanaan eksekusi obyek jaminan fidusia dalam Undang-Undang No 42 Tahun 1999. Penelitian ini menemukan bahwa peran notaris dalam pembuataan akta otentk jaminan fidusia dan pembebanan jaminan fidusia menjadi sangat krusial, alasanya, pemahaman dan interprestasi dari negoisasi para pihak harus dituangkan secara benar dan gamblang, khususnya mengenai klausul cidera janji. Pasca putusan Mahkamah Konstitusi a quo, Undang-Undang No 42 Tahun 1999 lebih memperhatikan perlindungan hukum bagi para pihak. Dalam hal pelaksanaan eksekusi, terjadi perubahan mengenai prinsip titel eksekutorial, mengharuskan syarat sukarela pada debitur untuk menyerahkan obyek jaminan.
\end{abstract}

Kata kunci: Jaminan, Eksekusi, Kepastian Hukum, Notaris

\section{Abstract}

The purpose of this article aims to analyze the authority of a notary public in making fiduciary deeds, legal protection, and the execution of fiduciary guarantees after the Decision of Constitutional Court number 18/PUU-XVII/2019. This article uses a normative juridical approach, This 
normative research used secondary data consisting of primary, secondary, and tertiary legal materials. The research describes the posisition of notary in making notarial deeds, describe how is the legal protection for the parties in law no 42 of 1999 on fiduciary guarantee, and how to do the execution of fiduciary collateral object. The results of this article show that, the notary do a crucial role in making of a fiduciary guarantee deeds to determine the default contract, and fiduciary law should provide legal certainty and protection for the parties as a fundamental condition to fulfil the basic legal values, then the voluntary of debtor becomes a matter of concern in the execution of collateral fiduciary.

Keywords: Collateral, Execution, Legal Certanity, Notary

\section{PENDAHULUAN}

\section{A. Latar Belakang}

Kepercayaan menjadi dasar dalam pengalihan hak kepemilikan dari pemberi fidusia kepada penerima fidusia pada perjanjian jamina fidusa, dengan syarat bahwa benda yang menjadi objeknya tetap berada di tangan pemberi fidusia. ${ }^{1}$ Seperti yang ditekankan Satrio, bahwa perjanjian jaminan fidusia hanyalah sebagai perjanjian ikutan dalam suatu perjanjian pokok. ${ }^{2}$ Dalam dunia bisnis, perjanjian pokok yang di maksud biasanya adalah perjanjian utang piutang atau perjanjian pinjam meminjam, perjanjian tersebut muncul lantaran debitur membutuhkan tambahan modal untuk memenuhi tuntutan usahanya. Pada prakteknya, sering ditemukan angsuran macet, hal ini dijelaskan oleh Suratman bahwa keadaan insolvensi bisa saja muncul dalam pelaksanaan kewajiban kontraktual, keadaan yang demikian menyebabkan debitor tidak bisa memenuhi tujuan perikatan, artinya debitur mengalami ketidakmampuan dalam memenuhi contractual obligation, berupa pelunasan atau pembayaran utang. Atas ketidakmampuan debitur tersebut, muncul hak tagih berbentuk eksekusi terhadap objek yang dibebani jaminan kebendaan pada kreditur. ${ }^{3}$ Adanya eksekusi terhadap objek yang dibebani jaminan kebendaan fidusia berdasarkan Undang-Undang No 42 Tahun 1999 dapat dilakukan dengan cara eksekusi melalui titel eksekutorial, objek jaminan fidusia dijual melalui pelelangan umum, dan barang yang

1 Hs Salim, Perkembangan Hukum Jaminan Di Indonesia (Jakarta: PT. Raja Grafindo Persada, 2011). H 55-57

2 J Satrio, Hak Jaminan Kebendaan, Hak Tanggungan (Bandung: Citra Aditya Bakti, 1997). H 110

3 Suratman, "Hak Melaksanakan Eksekusi Barang Jaminan Kebendaan Pasca Putusan Kepailitan,” Jurnal Hukum Dan Kenotariatan 2, no. 1 (2018): 128-147, https://doi.org/http://dx.doi.org/10.33474/hukeno.v2i1.1073. 
dibebani jaminan fidusia diperjualbelikan secara di bawah tangan dengan syarat terdapat kesepakatan para pihak.

Adanya pelaksanaan eksekusi jaminan yang bersifat eksekutorial ini, membedakan jaminan fidusia dengan jaminan yang lain, selain jaminan hak tanggungan. Hal ini menjadi sesuatu yang akan menjamin kedudukan kreditur dalam pelaksanaan kegiatan bisnis, lantaran kreditur mendapatkan hak yang di dahulukan dengan memegang sertifikat jaminan fidusia terhadap kreditur yang lain. Implikasi adanya titel ekskutorial dalam sertifikat jaminan fidusia, menyebabkan sering ditemui penggunaan jasa debt collector oleh kreditur dalam mengeksekusi objek jaminan fidusia, kadangkala justru membuat keadaan antara para pihak menjadi lebih rumit. Menurut Junaidi, besar potensi perlawanan yang diberikan oleh debitur apabila pelaksanaan eksekusi objek jaminan fidusia menggunakan jasa debt collector, tentu debitur menggunakan dalih self defense, maka potensi kekerasan, intimidasi, dan perampasan menjadi lebih besar dalam mengeksekusi objek jaminan fidusia. ${ }^{4}$

Seperti yang telah disebutkan di atas, bahwa pelaksanaan ekesuksi yang bersifat eksekutorial memberikan hak preferen kepada kreditur, tetapi bukan tanpa syarat, syarat yang utama adalah telah terjadi suatu cidera janji terlebih dahulu sebelum pelaksanaan eksekusi. Berbicara mengenai cidera janji ini, dalam UU Fidusia, tidak mengatur seberapa jauh aspek-aspek pelanggarannya secara khusus, hal ini tentu menjadi suatu hal yang ambigu bagi pihak-pihak terkait. Menurut penulis jika memang dalam UU terkait tidak menyampaikan seberapa jauh aspek cidera janji yang dilakukan oleh debitur yang akan menjadi dasar pelaksanaan eksekusi, maka dalam hal ini yang menjadi krusial adalah peran dari notaris. Menurut Dewi, notaris sebagai pejabat yang berwenang dalam membuat akta jaminan fidusia berdasarkan UU Fidusia, harus mampu menyadur pemikiran para pihak ke dalam klasula cidera janji pada akta otentik yang dibuat berdasarkan porsi masing-masing pihak. Kewenangan dan keahlian notaris dalam pembuatan akta jaminan fidusia, akan mampu menjaga hak dan kewajiban para pihak jika dikemudian hari ditemukan suatu cidera janji. ${ }^{5}$

Penulis berpendapat jika dalam hal pelaksanaan eksekusi eksekutorial oleh kreditur kemudian terjadi penolakan dan perlawanan dari debitur, maka perferensi dalam jaminan fidusia tidak terpenuhi dan justru muncul nilai-nilai ketidakadilan, di lain sisi, tidak adanya kekonkretan aspek

${ }^{4}$ Junaidi Abdullah, "Jaminan Fidusia Di Indonesia (Tata Cara Pendaftaran Dan Eksekusi)" (2016) 4:2 Bisnis J Bisnis dan Manaj Islam 115.

5 Retno Puspo Dewi, "Kekuatan Eksekutorial Sertifikat Jaminan Fidusia Berdasarkan Undang Undang Nomor 42 Tahun 1999 Tentang Jaminan Fidusia,” Jurnal Repertorium 4, no. 1 (2017): 73-81. 
cidera janji dalam undang-undang fidusia juga menjadi masalah tersendiri, tidak ada kepastian hukum yang mampu menjamin hak-hak dari debitur dalam melaksanakan kegiatan usaha nya apabila telah terikat dalam suatu perjanjian jaminan fidusia.

Tepat 1 tahun yang lalu pada bulan januari 2020, lahir putusan Mahkamah Konstitusi terkait pengujian Undang-Undang Fidusia terhadap Undang-Undang Dasar 1945. Dikutip dari tulisan redaksi Notarymagazines.com, ${ }^{6}$ putusan $\mathrm{MK}$ ini mengabulkan permohonan para Pemohon untuk sebagian dan selanjutnya menyatakan bahwa beberapa frasa beserta penjelasannya yang terdapat pada Pasal 15 ayat (2) beserta penjelasannya dan ayat (3) UU Fidusia bertentangan dengan UUD 1945 sepanjang tidak dimaknai sebagaimana tafsir yang diberikan oleh Majelis Hakim Mahkamah Konstitusi yang dimuat dalam Putusan terkait. Frasafrasa yang dimaksud yaitu, pertama, frasa "kekuatan eksekutorial" dan "sama dengan putusan pengadilan yang berkekuatan hukum tetap" (beserta penjelasannya) yang terdapat pada Pasal 15 ayat (2) dan kedua, yaitu frasa "cidera janji" yang terdapat pada Pasal 15 ayat (3) UU Fidusia.

\section{B. Perumusan Masalah}

Dari pengantar di atas mengenai perubahan substansi pokok dalam Undang-Undang Fidusia pasca putusan MK Nomor 18/PUU-XVII/2019, maka rumusan masalah yang diangkat dalam penulisan artikel ini menitikberatkan pada pembahasan, sejauh mana kewenagan notaris dalam pembuatan akta jaminan fidusia pasca putusan a quo? bagimana keadilan dan kepastian hukum dalam jaminan fidusia bagi para pihak pasca adanya putusan a quo? dan bagaimana eksekusi obyek jaminan fidusia pasca putusan a quo?

\section{METODE PENELITIAN}

Teori preskriptif digunakan untuk panduan dalam melakukan analisis dengan memberikan penilaian terhadap temuan fakta atau peristiwa hukum yang ada sesuai teori atau tidak. Dalam penelitian ini penulis menggunakan penelitian hukum yuridis normatif, asas-asas hukum yaitu penelitian yang difokuskan untuk mengkaji penerapan kaidah-kaidah atau norma-norma dalam hukum positif. Menurut Mukti dan Ahmad penelitian hukum normatif mencakup penelitian terhadap sistematika hukum, penelitian terhadap taraf sinkronisasi hukum, penelitian sejarah hukum dan penelitian

6 Notary Magazine Redaksi, "Kepastian Hukum Dan Perlindungan Hukum Jaminan Fidusia Pasca Putusan MK Nomor 18/PUU-XVII/2019,” 2020, https://notarymagazine.com/Kepastian-hukum-dan-perlindungan-hukum-jaminan-fidusiapasca-putusan -mk- nomor-18-puu-xvii-2019/. 
perbandingan hukum. ${ }^{7}$ Dalam penelitian normatif ini menggunakan pendekatan perundang-undangan (statute approach) yang didukung dengan bahan hukum primer berupa Undang-Undang Nomor 42 Tahun 1999 Jaminan Fidusia dan Putusan Mahkamah Konstitusi Nomor 18/PUUXVII/2019 yang berlaku dan bahan hukum sekunder berupa buku-buku hukum dan artikel yang relevan dengan isu hukum serta bersifat deskriptif analitis Data untuk penulisan ini diperoleh melalui bahan hukum primer undang-undang, dan bahan hukum sekunder, yaitu dalam bentuk buku teks oleh para ahli hukum.

\section{PEMBAHASAN}

Masih hangat di telinga kita pembicaraan intensif para akademisi dan praktisi hukum mengenai Putusan Mahkamah Konstitusi Nomor 18/PUUXVII/2019 mengenai pelaksanaan eksekusi Jaminan Fidusia. Berdasarkan Undang Undang Nomor 42 Tahun 1999 tentang Jaminan Fidusia, Mariam Daruz mengklasifikasikan jaminan fidusia sebagai sesuatu yang mengikat pihak lainya melalui jaminan kebendaan, perjanjian tentang jaminan ini adalah tambahan dari perjanjian pokok, atau sering disebut sebagai perjanjian acesoir. ${ }^{8}$ Berdasarkan Pasal 4 Undang-undang No 42 Tahun 1999 disebutkan bahwa Jaminan Fidusia merupakan perjanjian ikutan dari suatu perjanjian pokok yang menimbulkan kewajiban bagi para pihak untuk memenuhi suatu prestasi.

Putusan MK a quo menyatakan bahwa walaupun terdapat perubahan substansi pokok pada Undang Nomor 42 Tahun 1999 berkaitan dengan beberapa pasalnya, para pihak yang berkepentingan tetap harus merujuk ada Undang-Undang ini. Kemudian jika terkait mengenai eksekusi yang dilakukan kreditur, terjadi pelarangan eksekusi dengan cara paksaan atau tanpa prosedur. Maka Putusan MK nomor 18/PUU-XVII/2019 memberikan kepastian hukum terhadap apa yang sebelumnya tidak diatur secara konkret atau ambigu dan terhadap pasal-pasal yang di nyatakan tidak sesuai dengan nilai-nilai Undang-Undang Dasar Republik Indonesia tahun 1945.

\section{Kewenangan Notaris dalam Pembuatan Akta Jaminan Fiduisa}

Substansi dari Undang Nomor 42 Tahun 1999 memberikan prespektif yang berbeda bagi berbagai pihak dalam pelaksanaan suatu tindakan hukum berkaitan dengan adanya jaminan kebendaan pada suatu perjnajian utang-piutang, bagi kreditur adanya substansi pokok jaminan

${ }^{7}$ Mukti Fajar and Ahmad Yulianto, Dualisme Penelitian Hukum Normative Dan Empiris, cet. ke 4 (Yogyakarta: Pustaka Pelajar, 2017). H 150

8 Mariam Daruz, Mencari Sistem Hukum Benda Nasional (Bandung: Alumni, 2010). H 20 
fidusia memberikan kepastian terhadap kembalinya piutang, bagi debitur jaminan fidusia mampu menjamin kepastian dari hak kebendaan yang di jadikan agunan khusus, singkat kata, terdapat akibat hukum yang berbeda baik secara langsung atau tidak langsung bagi pihak-pihak terkait. Dalam perjanjian Jaminan fidusia, bukan melulu mengenai pihak pemberi jaminan fidusia dan penerima jaminan fidusia, ada pula pihak yang perlu diberi perhatian khusus, yaitu notaris.

Peran notaris menjadi krusial, lantaran pemberian atau pembebanan atas suatu objek Jaminan Fidusia dibuat dengan akta notaris dalam Bahasa Indonesia. ${ }^{9}$ Menurut Isdian, notaris harus mampu menuangkan kesepakatan para pihak dalam akta otentik setelah melewati proses negoisasi, khususnya dalam hal sejauh mana debitur dikatakan cidera janji(wanprestasi) ${ }^{10}$ Hal ini berkaitan, tidak diaturnya aspek-aspek cidera janji dalam UU Fidusia, berlatarbelakang hal tersebut, penulis berpendapat bahwa, sebaiknya notaris harus mampu memberikan pemahaman dan mengintegrasi prespektif para pihak yang mungkin saja berbeda, maka dalam bernegoisiasi menyatakan mengenai hak dan kewajiban masing-masing sesuai dengan porsinya, hal ini berlaku bagi perjanjian jaminan fidusia yang dibuat di hadapan notaris. Perlu digaris bawahi jika, perjanjian jaminan fidusia bisa saja di buat menggunakan akta di bawah tangan, tetapi untuk perjanjian pembebanan jaminan fidusia wajib menggunakan akta otentik, yang kemudian akan menjadi akta jaminan fidusia dan di daftarkan pada kantor pendaftran fidusia, agar sertifikat jaminan fidusia bisa terbit.

Dalam hal sertifikat jaminan fidusia sebagai lanjutan dari tahapan pendaftaran akta jaminan fidusia yang merupakan pernyataan konstitutif dari pejabat yang menerbitkan akta, mempunyai kekuatan eksekutorial yang sama dengan putusan Pengadilan yang telah memperoleh kekuatan hukum tetap, menurut Supianto hal tersebut mempunyai arti bahwa, penerima fidusia memiliki hak untuk langsung melakukan eksekusi benda jaminan fidusia dari penguasaan debitur, bahkan dengan upaya paksa, di jalan bahkan di rumah debitur. ${ }^{11}$ Perlu diketahui pula jika dalam UU fidusia, memberikan batasan dan larangan pada para pihak yang bersepakat untuk mengalihkan hak kepemilikan objek fidusia apabila pada satu waktu pemberi jamninan fidusia melakukan wanprestasi, maka kesepakatan

\footnotetext{
${ }^{9}$ Dewi, Supranote 1

${ }^{10}$ Isdian Anggraeny and Tongat Tongat, "Notary Liability over Their Involvement in Document Falsification Crime," Varia Justicia 16, no. 1 (2020): 31-38, https://doi.org/10.31603/variajusticia.v16i1.3307.

${ }^{11}$ Supianto, Hukum Jaminan Fidusia, Prinsip Publisitas Pada Jaminan Fidusia (Yogyakarta: Garudhawaca, 2011). H 161
} 
tersebut batal demi hukum. ${ }^{12}$ Setelah Putusan MK a quo, nilai keadilan bagi pihak debitur menjadi fokus utama, penerima fidusia tidak dapat melakuakan eksekusi objek jaminan fidusia secara serampangan, maksudnya tidak lagi bisa mengeksekusi secara sepihak, dimana saja, dan kapan saja, pasca putusan a quo, unsur kesukarelaan pemberi jaminan fidusia/debitur menjadi syarat berlakunya pelaksanaan eksekusi. Jika ternyata debitur tidak secara sukarela memberikan objek jaminan maka berlakulah Undang-Undang No 42 Tahun 1999 pada Pasal 29 yang memberikan tata cara eksekusi jaminan fidusia.

Dalam setiap putusannya, Mahkamah Konstitusi selalu mengutamakan asas-asas dalam hukum dan mendasarkan pada nilai-nilai yang adil, memiliki kepastian hukum dan seimbang, maka dari itu, sebagai pejabat yang berwenang dan sebagai seseorang yang paham mengenai pembuatan suatu kontrak, notaris harus menyajikan hal-hal yang sedemikian rupa seperti dalam putusan MK tersebut. Untuk itu, Notaris dalam pembuatan akta, perlu mengatur tentang aspek-aspek wanprestasi bagi debitur dan kapan wanprestasi bisa terjadi. Kemudian, yang perlu diberi perhatiaan lebih adalah pada hal kesukarelaan penyerahan objek jaminan, meliputi, kesediaan debitur dalam menyerahkan objek jaminan fidusia dan upaya-upaya yang dilakukan kreditur dalam menagih obyek jaminan fidusia. Notaris, Pemberi Fidusia dan Penerima Fidusia harus menyadari bahwa Jaminan Fidusia adalah lembaga jaminan dan bukan lembaga peralihan.

Maka hal-hal yang dilakukan oleh Notaris dalam membuat perjanjian Jaminan Fidusia adalah mengatur agar diperoleh keseimbangan, kepastian dan keadilan bagi Kreditur, Debitor dan pihak-pihak terkait. Jaminan Fidusia wajib mewujudkan perlindungan hukum baik kepastian hukum maupun keadilan bagi pihak-pihak yang oleh suatu perjanjian fidusia dan objek yang menjadi jaminan dalam perjanjian Jaminan Fidusia. Fatma memberikan kriteria pada aspek kecermatan dalam pembuatan perjanjian Jaminan Fidusia, terutama mengenai : ${ }^{13}$

a. Kejelasan spesifikasi barang yang dijadikan jaminan, seharusnya dideskripsikan melalui uraian yang lengkap dan jelas;

b. Adanya klausul yang mencerminkan aturan-aturan dalam UU Fidusia dan klausul yang memberikan perlindungan hukum bagi penerima jaminan fidusia;

12 Pasal 33 Peraturan Perundang-undangan Republik Indonesia, "Undang-Undang No 42 Tahun 2009" (n.d.).

${ }^{13}$ Fatma Paparang, "Implementasi Jaminan Fidusia Dalam Pemberian Kredit Di Indonesia," Jurnal LPPM Bidang EkoSosBudKum 1, no. 2 (2014): 56-70. 
c. Adanya kejelasan mengenai status barang yang dibebani jaminan fidusia, melalui pernyataan oleh pemberi jaminan fidusia yang seluruhnya tunduk pada aturan-aturan UU fidusia.

Seperti yang telah diutarakan penulis, bahwa Undang Nomor 42 Tahun 1999 tidak mengatur sejauh mana debitor dikatakan wanprestasi dan kapan bisa dinyatakan wanprestasi, hal ini disebabkan dalam undangundang tersebut pada pokoknya tidak berperan sebagai lembaga peralihan hak tetapi hanya menjadi lembaga jaminan saja, ini tercantum jelas pada pasal 33 Undang-Undang No 42 Tahun 1999, bahwa benda yang menjadi agunan dalam jaminan fidusia tidak bisa di miliki oleh kreditur sebagai penerima fidusia.

Menurut Purwahid, bagi pemberi dan penerima jaminan fidusia sebagai subyek hukum jaminan fidusia, dalam membuat suatu perjanjian jaminan fidusia harus berdasarkan asas itikad yang menjadi dasar pondasi dalam kontrak, sehingga kontrak yang dimaksud tersebut dapat menajdi sandaran hukum yang baik bagi para pihak dalam melaksanakan contractual obligation. ${ }^{14}$ Maka khususnya bagi notaris, ditekankan oleh Djoni, dalam pembuatan akta jaminan fidusia, harus mengandung klasula yang jelas dan unsur-unsur perjanjian yang baik dan benar, sebagai bentuk manifestasi dari Undang-Undang No 42 Tahun 1999, klasula dan unsur tersebut meliputi, bagaimana para pihak memaknai kriteria suatu unsur cidera janji dan tenggat waktunya, bagaimana prosedur penyerahan barang jaminan fidusia, apa saja yang tidak boleh dilakukan para pihak dalam perjanjian, dan bagaimana proses pelaksanaan eksekusi jika pemberi fidusia cidera janji. ${ }^{15}$

Apa yang seharusnya dilakukan notaris yang sudah terlanjur ditunjuk sebagai pembuat akta jaminan fidusia pasca terbitnya putusan MK a quo? Menurut penulis para pihak perlu melakukan renegoisasi yang mencakup ruang lingkup kepastian dan perlindungan hukum dalam perjanjian di masa yang akan datang, tentu tetap dalam koridor negoisasi yang masuk akal demi mencapai kesepakatan-kesepakatan yang tidak berat sebelah, dalam hal pendampingan oleh notaris, sebaiknya dirinya menyarankan klausulklausul tambahan yang akan menajmin terpenuhinya tujuan daripada perjanjian, atau setidaknya sebagai jalan alternatif apabila kelak para pihak berperilaku seleweng, saran tersebut berlaku dalam perjanjian pokok dan perjanjian jaminan fidusia baik yang berbentuk otentik ataupun dibawah tangan. Menurut Ahdiana, disinilah urgensi tahapan dalam perjanjian berperan penting, yaitu negoisasi, yang merupakan sarana bagi para pihak

${ }^{14}$ Purwahid, Hukum Jaminana Fidusia (Semarang: Fakultas Hukum Universitas Diponegoro, 2008). H 34-35

15 Djoni S. Gozali and Rachmadi Usman, Hukum Perbankan (Jakarta: Sinar Grafika, 2012). H 342 
untuk mengadakan komunikasi dua arah untuk mencapai kesepakatan sebagai akibat adanya kesamaan atau perbedaan kepentingan para pihak. ${ }^{16}$

\section{Aspek Kepastian Hukum serta Keadilan dalam Jaminan Fidusia}

Salah satu asas dalam hukum jaminan fidusia adalah publisitas yang dilakukan oleh pihak yang memiliki kepentingan terhadap objek jaminan, asas publisitas ini berperan mutlak, maksudnya, dengan adanya suatu kewajiban atas+

pendaftaran akta jaminan fidusia untuk memenuhi asas publisitas ini, maka unsur traparansi dan kepastian hukum bagi hak kepemilikan dan kepentingan para pihak. Sifat asas publisitas yang imperative akan memberikan kepastian kepada benda jaminan, memberikan hak preferen bagi kreditur pemegang sertifikat jaminan fidusia, dan menjamin pengembalian piutang, serta mengikat pihak ketiga terhadap benda yang di jaminkan.

Bentuk kepastian hukum dan keadilan yang seharusnya didapatkan oleh para pihak menjadi syarat fundamental pelaksanaan kegiataan jaminan, dalam konteks UU Fidusia, syarat fundamental tersebut akan mampu memberikan perlindungan hukum bagi obyek dan subyek jaminan fidusia, dan akan memberikan kepastian mengenai kedudukan antara para pihak. Menurut penulis, UU Fidusia sendiri belum secara gamblang mencerminkan nilai kepastian hukum dan keadilan bagi para pihak karena ada beberapa aspek yang tidak seimbang dan masih timpang dalam pelaksanaan jaminan fidusia di masyarakat. Menurut penulis nilai keadilan dan kepastian hukum dalam rangka melindungi para pihak, hanya diberikan pada penerima jaminan fidusia saja. Hal ini terwujud di dalam banyak peristiwa hukum yang terjadi, bagi kreditur, UU Fidusia memberikan perlindungan hukum berupa pemberian hak preferen dan kepastian pelunasan piutang misalnya, adalah wujud perlindungan hukum yang di dapatkan oleh kreditur, walaupun tetap saja tergantung pada kesukarelaan debitur di dalam pelaksanaan eksekusi jaminan nya. Sekarang coba bandingkan dengan keadilan dan kepastian hukum bagi debitur, menurut penulis, tidak diaturnya aspek sejauh mana dan kapan wanprestasi atau cidera janji secara terperinci dalam jaminan fidusia adalah bentuk ketidakadilaan dan ketidakpastian hukum. UU Fidusia bagi debitur hanya menjamin bahwa secara yuridis kepemilikan obyek jaminan tetap menjadi hak milik dari debitur.

Pada dasarnya secara dasolen, seharusnya hukum jaminan fidusia memberikan kepastian dan perlindungan hukum bagi para pihak terkait, tetapi secara dasein, masih diketemukan ketidakadilan dan ketidakpastian

16 Ahdiana Yuni Lestari and Dkk, Dasar-Dasar Pembuatan Aqad \& Kontrak (Yogyakarta: Lab Hukum Universitas Muhammadiyah Yogyakarta, 2008). H 95 
hukum dalam proses pelaksanaan eksekusi obyek jaminan fidusia. Secara logika hukum, jaminan adalah wadah bagi para pihak untuk meyakinkan pihak yang lain untuk kelak akan memenuhi suatu prestasi, sedikit contoh bahwa ketika kreditur melakukan eksekusi dengan upaya-upaya yang seleweng maka muncul ketidakadilan bagi debitur, sebaliknya jika terbukti debitur melakukan wanprestasi namun tidak sesegera mungkin secara sukarela menyerahkan agunan, maka muncul ketidakadilan bagi kreditur. Memang secara hukum, upaya-upaya tidak etis yang dilakukan kreditur untuk mengeksekusi obyek jaminan fidusia tidak dapat dipersalahkan, lantaran berdasar pada Pasal 15 ayat (2) dan ayat (3) UU Jaminan Fidusia timbul kekuatan eksekusi yang dapat dilaksanakan sendiri oleh pemegang jaminan fidusia (kreditur) yang kemudian banyak menimbulkan permasalahan, baik terkait dengan konstitusionalitas norma maupun implementasi.

Dalam Pasal 15 ayat (2) UU Fidusia yang memberikan "titel eksekutorial" terhadap sertifikat fidusia dan "mempersamakan dengan putusan pengadilan yang telah mempunyai kekuatan hukum tetap" yang di dalamnya terkandung makna bahwa sertifikat fidusia mempunyai kekuatan eksekusi tanpa disyaratkan adanya putusan pengadilan yang didahului oleh adanya tuntutan hak dan pelaksanaan eksekusinya dianggap sederajat dengan putusan pengadilan yang telah mempunyai kekuatan hukum tetap.

Dari penjelasan di atas, kita dapat mengetahui bahwa penerima jaminan fidusia/kreditur diberikan hak eksklusif melalui sertifikat fidusia untuk melakukan perbuatan eksekusi terhadap branag jaminan yang dikuasai pemberi jaminan fidusia/debitur, apabila pada satu waktu dinyatakan bahwa si debitur terbukti telah melakukan wanprestasi. Perlu diingat perjanjian fidusia memberikan hak milik kebendaan untuk berpindah menjadi hak penerima fidusia (kreditur), sehingga kreditur dapat setiap saat mengambil objek jaminan fidusia dari debitur dan selanjutnya menjual kepada siapapun dengan kewenangan penuh ada pada kreditur dengan alasan karena kekuatan eksekusi dari sertifikatnya telah dipersamakan dengan putusan pengadilan yang telah mempunyai kekuatan hukum tetap. Dari hal ini, menunjukan bahwa begitu banyak hak-hak baru bagi kreditur yang memiliki kekuatan hukum setelah terjadi perjanjian pembebanan jaminan fidusia.

Selanjutnya, jika kreditur diberikan eksklusifitas dalam menentukan kapan cidera janji oleh debitur maka telah terjadi pengabaian hak debitur yang seharusnya juga mendapat perlindungan hukum yang sama, yaitu hak untuk mengajukan atau mendapat kesempatan pembelaan diri atas adanya dugaan telah cidera janji (wanprestasi) dan kesempatan mendapatkan hasil penjualan objek jaminan fidusia dengan harga yang wajar. Inilah salah satu bentuk ketidakadilan dalam pelaksanaan perjanjian fidusia, bahwa terhadap 
perkara wanprestasi yang dilakukan oleh debitur, kreditur memiliki hak eksklusif untuk menilai secara sepihak apakah debitur telah melakukan cidera janji. Maka sekiranya asas keseimbangan dan keadilan dalam pelaksanaan perjanjian jaminan harus diberikan pada pihak-pihak yang berkepentingan.

Salah satu urgensi pembeharuan hukum jaminan fidusia di Indonesia adalah untuk memperjelas bagaimana pelaksanaan eksekusi yang dapat dilakukan dan memberikan kriteria yang menekankan sejauh mana perbuatan debitur itu bisa dikatakan sebagai suatu "cidera janji”'(wanprestasi), perlu diberikan suatu kepastian hukum apakah keterlambatan pembayaran angsuran termasuk cidera janji atau apakah cidera janji hanya bisa dinyatakan ketika angsuran sudah jatuh tempo, Undang-Undang No 42 Tahun 1999 seharusnya memberikan perlindungan hukum sesuai porsi masing-masing pihak agar tercapai tujuan daripada apa yang dicita-citakan oleh para pihak. Khifni mengutip pendapat Gustav Radbruch, bahwa terdapat unsur penting dalam hukum jika dikaitkan dengan hukum jaminan fidusia, yaitu meliputi keadilan, finalitas dan kepastian, pada dasarnya, UU Jaminan Fidusia bercita-cita untuk memberikan kepastian hukum bagi kreditur atas piutangnya dan memberikan perlindungan hukum bagi pihak-pihak terkait. ${ }^{17}$

\section{Eksekusi Obyek Jaminan Fidusia Pasca Putusan MK Nomor 18/PUU- XVII/2019}

Pada prakteknya sering kali ditemukan angsuran dari perikatan pada perjanjian macet, menurut Budi Setia, debitur telah melakukan suatu wanprestasi atau cidera janji, jika dalam pelaksanaan prestasi ternyata terdapat hal seperti itu dan dalam perjanjian acesoir menjamkian obyek menggunakan fidusia, maka demi menjamin piutang kreditur terpenuhi, berlakulah Pasal 29 Undang-Undang Nomor 42 Tahun 1999 tentang Jaminan Fidusia, menyatakan bahwa pelaksanaan eksekusi bisa dilakukan. ${ }^{18}$ Perihal benda modal yang dibebani hak jaminan fidusia, menurut Isnaini, penguasaan barang yang diagunkan harus diberikan sepenuhnya kepada pemberi jaminan fidusia/debitur, inilah dasar pemikiran fidusia yaitu kepercayaan, agar nantinya usaha yang sedang dijalankan oleh debitur mampu dikelola dengan baik dengan bantuan objek jaminan fidusia

${ }^{17}$ Khifni Kafa Rufaida, “Tinjauan Hukum Terhadap Eksekusi Objek Jaminan Fidusia Tanpa Titel Eksekutorial Yang Sah,” Refleksi Hukum: Jurnal Ilmu Hukum 4, no. 1 (2019): 21-40, https://doi.org/10.24246/jrh.2019.v4.i1.p21-40.

18 Budi Setia, "Permohonan Ekseskusi Kepada Pengadilan Negeri Berkaitan Dengan Perjanjian Fidusia Terhadap Jaminan Yang Di Gelapkan," Jurnal Cendikia Hukum 3, no. 1 (2017): 99-107. 
tersebut, jika usahanya berjalan lancea, maka pengahsilan itu bisa digunakan memenuhi pembayaran utang sampai selesai. ${ }^{19}$ Jadi secara yuridis, hak kepemilikan benda tetap berada dalam genggaman debitur, hal ini lantaraan benda tetap di kuasai oleh debitur serta penyerahan barang atau levering dilakukan tidak secara nyata. Disampaikan pula oleh Gunawan, jika suatu saat terjadi cidera janji oleh debitur maka dilakukan suatu eksekusi terhadap benda yang dijadikan jaminan fidusia, yang dijalankan melalui cara: ${ }^{20}$

a. Pelaksanaan titel eksekutorial, karena dalam sertifikat jaminan fidusia tercantumkan kata Demi Keadilan Berdasarkan Ketuhanan Yang Maha Esa.

b. Penjualan benda yang menjadi jaminan fidusia atas kekuasaan Penerima Fidusia sendiri melalui pelelangan umum.

c. Penjualan di bawah tangan dilakukan berdasarkan kesepakatan antara Pemberi dan penerima fidusia, di umumkan dalam surat kabar daerah tersebut.

Pasca Putusan MK a quo, disebutkan bahwa cara eksekusi benda jaminan, terpdapat hal pokok yang harus di garis bawahi, yaitu berkaitan dengan tindakan sukarela dari debitor terhadap eksekusi yang dilakukan oleh kreditur. Dalam hal debitur telah sukarela untuk menyerahkan benda jaminan karena dirinya sadar bahwa telah melakukan suatu cidera janji, maka obyek jaminan tersebut bisa dilanjutkan untuk di eksekusi oleh kreditur, baik penjualan melalui pelelangan resmi maupun pelelengan $\mathrm{d}$ bawah tangan. Kemudian, dalam hal debitur tidak secara sukarela menyerahkan benda yang menjadi jamininan fidusia, maka kreditur tidak bisa secara paksa untuk melakukan eksekusi, cara yang bisa dilakukan oleh kreditur dalam hal yang demikian, adalah melakukan mekanisme dan prosedur hukum dalam pelaksanaan eksekusi jaminan fidusia yang sesuai dengan Undang Nomor 42 Tahun 1999.

Sebelum lahirnya putusan Mahkamah Konstitusi Nomor 18/PUUXVII/2019, sertifikat fidusia memiliki kekuatan yang bersifat titel eksekutorial (Pasal 15 UU Fidusia), maksudnya pelaksanaan eksekusi yang akan dilakukan oleh kreditur atau penerima jaminan fidusia melalui sertifikat fidusia tidak perlu melalui tata cara atau prosedur eksekusi seperti pada pengadilan negeri setempat (Pasal 196 HIR atau Pasal 208 RBg), karena sertifikat fidusia dianggap telah memiliki kekuatan hukum tetap sebanding dengan putusan pengadilan, sehingga pemegang sertifikat ini

\footnotetext{
${ }^{19}$ Isnaini Moch, Pengantar Hukum Jaminan Kebendaan (Surabaya: : Revka Petra Media, 2016). H 8

${ }^{20}$ Widjaja Gunawan and Dkk, Jaminan Fidusia (Bandung: Sinar Grafika, 2000). H 160
} 
berhak untuk mengalihkan penguasaan objek jaminan fidusia kapanpun dan dimanapun, dengan syarat pemberi fidusia telah melakukan cidera janji. Sertifikat jaminan fidusia mengandung hak eksekutorial bagi penerima jaminan fidusia, terwujud dalam irah-irah "Demi Keadilan Berdasarkan Ketuhanan Yang Maha Esa" merupakan pernyataan yang mengandung suatu kewenangan bahwa dokumen (naskah) telah memiliki kekuatan eksekusi (pelaksanaan secara paksa) dengan bantuan alat negara. Secara praktek yang ditemukan, pemahaman mengenai titel eksekutorial dalam sertifikat jaminan fidusia adalah kreditur baik sendiri ataupun menggunakan jasa keamanan sesuai dalam peraturan OJK, melakukan eksekusi secara paksa terhadap obyek jaminan fidusia. Hal tersebut tidak terjadi sekali saja, tetapi seperti sudah menjadi kebiasaan para kreditur untuk melakukan kegiatan eksekusi dengan cara tersebut.

Maka dengan adanya Putusan MK a quo, terhadap adanya titel eksekutorial tersebut, Mahkamah Konstitusi memberikan kepastian hukum bahwa, adanya paksaan dalam melakukan eksekusi adalah tidak sesuai dengan nilai-nilai kepatutan, kesusilaan dan ketertiban umum. Maka dari itu, para pihak yang menjadi subyek jaminan fidusa, setelah adanya putusan ini diwajibkan untuk mampu mencerna dan mengaplikasikan nilai-nilai dasar hukum dalam pelaksanaan eksekusi jaminan fidusia, bahwa, pemegang sertifikat jaminan fidusia sekalipun terdapat titel eksekutorial dengan irah-irah nya, jika memang debitur tidak secara sukarela menyerahkan benda jaminan, maka menurut Tan, hal yang harus ditempuh oleh kreditur adalah melakukan pengajuan eksekusi pada pengadilan negeri setempat melalui form permohonan eksekusi, kemudian pelaksanaan eksekusi oleh pengadilan dilakukan berdasarkan prosedur eksekusi. ${ }^{21}$

Mengenai perihal Eksekusi obyek jaminan, Yahya berpendapat jika tindakan hukum tersebut adalah layak dilakukan oleh pengadilan kepada pihak yang kalah dalam suatu perkara demi menjaga asas kepastian hukum dan keadilan bagi para pihak. ${ }^{22}$ Terdapat perbedaan prepekstif hukum dalam memandang Putusan MK a quo, khususnya dalam cakupan sejauh mana titel eksekutorial dapat diperlakukan sama seperti putusan pengadilan yang berkekuatan hukum tetap dan mengikat, pasca putusan a quo, syarat yang harus dipenuhi adalah kesukarelaan pihak pemberi jaminan fidusia untuk memberikan barang jaminan, jika ternyata diketahui bahwa debitur

21 Tan Kamelo, Hukum Jaminan Fidusia Suatu Kebutuhan Yang Didambakan (Yogyakarta: Alumni, 2014). H 103

${ }^{22}$ Yahya M Harahap, Ruang Lingkup Permasalahan Eksekusi Bidang Perdata (Yogyakarta: Gramedia, 1998). H 12 
tidak secara sukarela, maka harus sesuai dengan ketentuan Pasal 196 HIR atau Pasal $208 \mathrm{RBg}$, selengkapnya adalah: ${ }^{23}$

"Jika pihak yang dikalahkan tidak mau atau lalai untuk memenuhi isi keputusan itu dengan damai, maka pihak yang menang memasukkan permintaan, baik dengan lisan, maupun dengan surat, kepada ketua, pengadilan negeri yang tersebut pada ayat pertama pasal 195, untuk menjalankan keputusan itu Ketua menyuruh memanggil fihak yang dikalahkan itu serta memperingatkan, supaya ia memenuhi keputusan itu di dalam tempo yang ditentukan oleh ketua, yang selama -lamanya delapan hari."

Kreditur dianggap masih memiliki hak eksklusif dalam jaminan fidusia, kewenangan tersebut tetap dapat melekat sepanjang tidak terdapat permasalahan dengan kepastian waktu perihal kapan pemberi hak fidusia (debitur) telah "cidera janji" (wanprestasi) dan debitur secara suka rela menyerahkan benda yang menjadi objek dari perjanjian fidusia kepada kreditur untuk dilakukan penjualan sendiri. Dengan kata lain, dalam hal ini, pemberi fidusia (debitur) mengakui bahwa dirinya telah "cidera janji" sehingga tidak ada alasan untuk tidak menyerahkan benda yang menjadi objek perjanjian fidusia kepada penerima fidusia (kreditur) guna dilakukan penjualan sendiri oleh penerima fidusia (kreditur).

Oleh karenanya terdapat hak eksklusif yang diterima kreditur untuk melakukan parate eksekusi terhadap obyek fidusia dengan syarat adanya kesukarelaan dari pihak debitur untuk menyerahkan barang agunan. Jika pada kenyataanya pihak debitur tidak menghindahkan pernyataan kreditur bahwa dirinya telah melakukan wanprestasi dan terdapat tangkisan untuk melakukan levering barang agunan secara sukarela, maka pihak kreditur yang juga bertindak sebagai penerima jaminan fidusia dilarang untuk melakukan eksekusi sendiri sekalipun memegang sertifikat jaminan fidusia, tetapi seharusnya melakukan pengajuan tuntutan hak atas pelaksanaan eksekusi melalui pengadilan setempat. Maka diharapkan kepentingan dan hak para pihak yang berkepentingan seimbang sesuai dengan porsinya.

\section{KESIMPULAN}

Pasal 15 Undang-Undang No 42 Tahun 1999 Tentang Jaminan Fidusia mengandung ketidakjelasan hukum dalam frasa "cidera janji" mengenai interprestasi locus debitur dapat dinyatakan wanprestasi.. Maka dalam hal ini, jika para pihak bersepakat untuk melaksanakan perjanjian fidusia dalam bentuk akta otentk, notaris berperan untuk mengarahkan para pihak agar dapat menyepakati klasul-klasul tertentu, seperti kejelasan kapan

${ }^{23}$ Pasal 196 Herzein Inlandsch Reglement atau Pasal 208 Rechtreglement voor de Buitegewesten 
wanprestasi bisa terjadi dan bagaimana proses pelaksanaan eksekusi, peran notaris dibutuhkan demi mencapai kepastian dan perlindungan hukum bagi para pihak.

Dalam perkembangan pelaksanaan perjanjian Jaminan fidusia di Indonesia sampai sekarang belum mencerminkan terpenuhinya cita-cita hukum perjanjian terhadap pihak-pihak yang berkepentingan, sebaiknya dalam pembaharuan hukum jaminan fidusia diharapkan mampu untuk memberikan perlindungan, kepastian, dan keseimbangan hukum bagi para pihak, karena unsur-unsur tersebut adalah bersifat fundamental dalam pelaksanaan norma hukum

Putusan Mahkamah Konstitusi Nomor 18/PUU-XVII/2019 tidak menghilangkan kewenangan eksklusif kreditur dalam melakukan parate eksekusi melalui sertifikat jaminan fidusia, selama pihak debitur memberikan kesukarelaannya untuk melakukan penyerahan barang agunan fidusia dan telah terjadi suatu wanprestasi terlebih dahulu. Sebaliknya, jika tidak terdapat pengakuan atas wanprestasi dari debitur dan tidak ada kesukarelaan dalam penyerahan barang agunan fidusia, maka penerima jaminan fidusia harus melakukan tuntutan haknya pada pengadilan negeri setempat yang prosedurnya berdasarkan pada Pasal 196 HIR atau Pasal 208 $\mathrm{RBg}$.

\section{DAFTAR PUSTAKA}

\section{Buku}

Daruz, Mariam. Mencari Sistem Hukum Benda Nasional. Bandung: Alumni, 2010.

Fajar, Mukti, and Ahmad Yulianto. Dualisme Penelitian Hukum Normative Dan Empiris. Cet. ke 4. Yogyakarta: Pustaka Pelajar, 2017.

Gozali, Djoni S., and Rachmadi Usman. Hukum Perbankan. Jakarta: Sinar Grafika, 2012.

Gunawan, Widjaja, and Dkk. Jaminan Fidusia. Bandung: Sinar Grafika, 2000.

Harahap, Yahya M. Ruang Lingkup Permasalahan Eksekusi Bidang Perdata. Yogyakarta: Gramedia, 1998.

Kamelo, Tan. Hukum Jaminan Fidusia Suatu Kebutuhan Yang Didambakan. Yogyakarta: Alumni, 2014.

Lestari, Ahdiana Yuni, and Dkk. Dasar-Dasar Pembuatan Aqad \& Kontrak. Yogyakarta: Lab Hukum Universitas Muhammadiyah Yogyakarta, 2008.

Moch, Isnaini. Pengantar Hukum Jaminan Kebendaan. Surabaya: : Revka Petra Media, 2016.

Peraturan Perundang-undangan Republik Indonesia. Undang-Undang No 42 
Tahun 2009 (n.d.).

Purwahid. Hukum Jaminana Fidusia. Semarang: Fakultas Hukum Universitas Diponegoro, 2008.

Salim, Hs. Perkembangan Hukum Jaminan Di Indonesia. Jakarta: PT. Raja Grafindo Persada, 2011.

Satrio, J. Hak Jaminan Kebendaan, Hak Tanggungan. Bandung: Citra Aditya Bakti, 1997.

Supianto. Hukum Jaminan Fidusia, Prinsip Publisitas Pada Jaminan Fidusia. Yogyakarta: Garudhawaca, 2011.

\section{Jurnal}

Abdullah, Junaidi. "Jaminan Fidusia Di Indonesia (Tata Cara Pendaftaran Dan Eksekusi)." BISNIS : Jurnal Bisnis Dan Manajemen Islam 4, no. 2 (2016): 115. https://doi.org/10.21043/bisnis.v4i2.2693.

Anggraeny, Isdian, and Tongat Tongat. "Notary Liability over Their Involvement in Document Falsification Crime." Varia Justicia 16, no. 1 (2020): 31-38. https://doi.org/10.31603/variajusticia.v16i1.3307.

Dewi, Retno Puspo. "Kekuatan Eksekutorial Sertifikat Jaminan Fidusia Berdasarkan Undang Undang Nomor 42 Tahun 1999 Tentang Jaminan Fidusia." Jurnal Repertorium Volume 4, no. 1 (2017): 73-81.

Paparang, Fatma. "Implementasi Jaminan Fidusia Dalam Pemberian Kredit Di Indonesia." Jurnal LPPM Bidang EkoSosBudKum 1, no. 2 (2014): 56-70.

Rufaida, Khifni Kafa. "Tinjauan Hukum Terhadap Eksekusi Objek Jaminan Fidusia Tanpa Titel Eksekutorial Yang Sah.” Refleksi Hukum: Jurnal Ilmu Hukum 4, no. 1 (2019): 21-40. https://doi.org/10.24246/jrh.2019.v4.i1.p21-40.

Suratman. "Hak Melaksanakan Eksekusi Barang Jaminan Kebendaan Pasca Putusan Kepailitan.” Jurnal Hukum Dan Kenotariatan 2, no. 1 (2018): 128-47. https://doi.org/http://dx.doi.org/10.33474/hukeno.v2i1.1073.

Setia, Budi. "Permohonan Ekseskusi Kepada Pengadilan Negeri Berkaitan Dengan Perjanjian Fidusia Terhadap Jaminan Yang Di Gelapkan." Jurnal Cendikia Hukum 3, no. 1 (2017): 99-107.

\section{Webpage}

Redaksi, Notary Magazine. "Kepastian Hukum Dan Perlindungan Hukum Jaminan Fidusia Pasca Putusan MK Nomor 18/PUU-XVII/2019," 2020. https://notarymagazine.com/Kepastian-hukum-danperlindungan-hukum-jaminan-fidusia-pasca-putusan -mk- nomor-18puu-Xvii-2019/. 